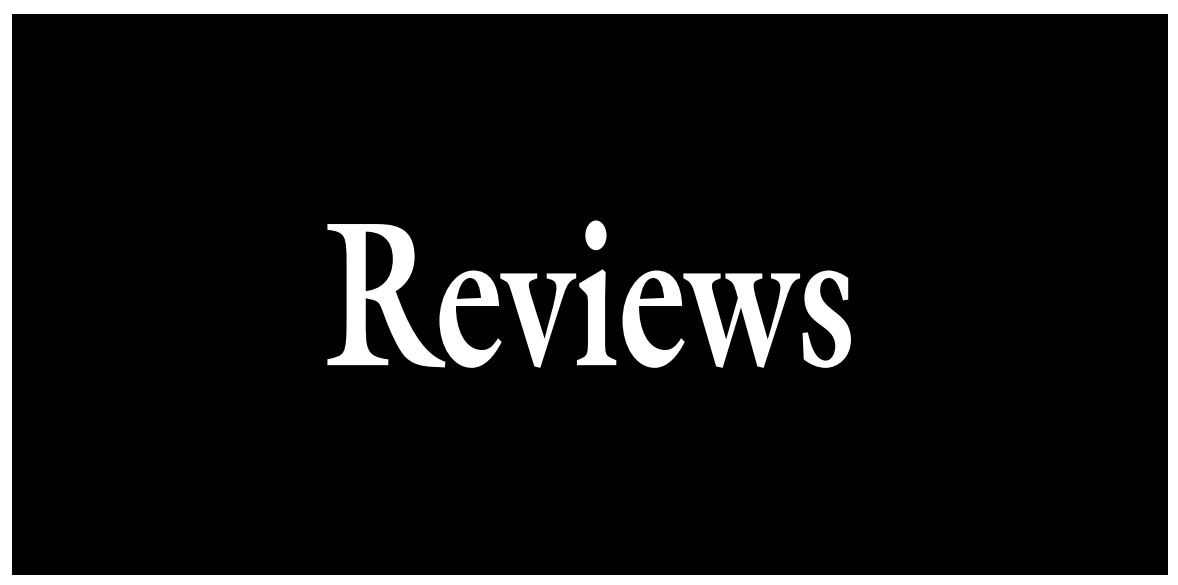

\section{Factors Affecting Nutrient Availability, Placement, Rate, and Application Timing of Controlled-release Fertilizers for Florida Vegetable Production Using Seepage Irrigation}

\author{
Luther C. Carson and Monica Ozores-Hampton ${ }^{1}$
}

ADDITIONAL INDEX wORDs. enhanced-efficiency fertilizer, fertilizer placement, openbed, plasticulture, soil moisture, soil $\mathrm{pH}$, soil temperature

SUMMARY. This publication summarizes the factors influencing controlled-release fertilizer (CRF) nutrient release, CRF placement, CRF rate, and CRF application timing for the two major seepage-irrigated vegetable production systems (plasticulture and open-bed) in Florida. One of several best management practices for vegetable production, CRF helps growers achieve total maximum daily loads (TMDLs) established in Florida under the Federal Clean Water Act. Several factors intrinsic to CRF and to the vegetable production systems affect CRF nutrient release, making implementation of CRF fertility programs challenging. Increasing or decreasing soil temperature increases or decreases nutrient release from CRF. Soil moisture required for uninhibited plant growth is within the soil moisture range for optimum CRF nutrient release. CRF substrate affects nutrient release rate, which is inversely related to coating thickness and granule size. Soil microbes, soil texture, and soil $\mathrm{pH}$ do not influence nutrient release rate. Field placement of CRFs in seepage-irrigated, plasticulture, and open-bed production should be in the bottom mix at bed formation and soil incorporated or banded at planting, respectively. In plasticulture production systems, soil fumigation and delayed planting for continuous harvest may add a 14- to 21-day lag period between fertilization and planting, which along with different season lengths will influence CRF release length selected by growers. Using a hybrid fertilizer system in plasticulture production or incorporating CRF at planting in open-bed production allows for up to a $\mathbf{2 5 \%}$ reduction in the nitrogen $(\mathrm{N})$ rate needed.

$\mathrm{T}$ he U.S. Environmental Protection Agency (USEPA) and Florida Department of Environmental Protection (FDEP) enforce the Federal Clean Water Act of 1972 and the Florida Restoration Act of 1999 , both of which mandate improved water quality (Bartnick et al.,

Southwest Florida Research and Education Center (SWFREC), University of Florida, Immokalee, FL 34142

${ }^{1}$ Corresponding author. E-mail: ozores@ufl.edu.
2005). The Federal Clean Water Act tion of impaired water bodies and Section 303(d) requires identifica- establishment of TMDLs for pollutants that may enter water bodies with a specified designated use (USEPA, 2009). Florida BMPs are a series of voluntary production practices that help the vegetable industry meet TMDLs by minimizing nutrient and sediment runoff (Bartnick et al., 2005). These BMPs may be implemented individually or as a group; however, each BMP must be "technically feasible, economically viable, socially acceptable, and based on sound science" (Bartnick et al., 2005).

The application of CRF is one of the several BMPs in the "Florida Vegetable and Agronomic Crop BMP manual" (Bartnick et al., 2005). Understanding CRF nutrient release factors and CRF performance in each of the vegetable production systems using subsurface ("seepage") irrigation will help optimize the use of CRF in Florida. Seepage irrigation consists of managing a water table perched above a slowly permeable soil layer (a spodic or textural horizon) located 24 to 36 inches below the bed surface (OzoresHampton et al., 2012). Ground or surface water is pumped into field ditches, which then moves horizontally between adjacent ditches (spaced 40 to $60 \mathrm{ft}$ ). When waters from adjacent ditches meet, the so-called perched water table is formed, thereby irrigating the crop by capillarity. The perched water table may also serve as a frost protection measure by elevating the water table to near the soil surface (Ozores-Hampton et al., 2011). However, raising the water table solubilizes fertilizer nutrients that are subject to loss through leaching upon lowering the water table or dropout by gravitational convection given appropriate conditions, such as a high water table, low soil organic matter, and high fertilizer rates (Bonczek and $\mathrm{McNeal}$, 1996). The objective of this publication is to summarize the factors influencing nutrient release from CRF, and their appropriate placement, rate, and application timing in both plasticulture

\begin{tabular}{llll}
\hline $\begin{array}{l}\text { Units } \\
\text { To convert U.S. to SI, } \\
\text { multiply by }\end{array}$ & U.S. unit & SI unit & $\begin{array}{l}\text { To convert SI to U.S., } \\
\text { multiply by }\end{array}$ \\
\hline 0.3048 & $\mathrm{ft}$ & $\mathrm{m}$ & 3.2808 \\
2.54 & inch $(\mathrm{es})$ & $\mathrm{cm}$ & 0.3937 \\
25.4 & inch $(\mathrm{es})$ & $\mathrm{mm}$ & 0.0394 \\
1.1209 & lb/acre & $\mathrm{kg} \cdot \mathrm{ha}^{-1}$ & 0.8922 \\
$\left({ }^{\circ} \mathrm{F}-32\right) \div 1.8$ & ${ }^{\circ} \mathrm{F}$ & ${ }^{\circ} \mathrm{C}$ & $\left({ }^{\circ} \mathrm{C} \times 1.8\right)+32$
\end{tabular}


and open-bed seepage-irrigated vegetable production systems in Florida.

\section{What is controlled-release fertilizer?}

Controlled-release fertilizer belongs to a group of fertilizers called enhanced-efficiency fertilizers (EEFs), which may increase the fertilizer use efficiency by maintaining nutrients, such as nitrogen $(\mathrm{N})$, phosphorus $(\mathrm{P})$, and potassium $(\mathrm{K})$, near the point of placement and reducing leaching losses rather than becoming an environmental pollutant (Lammel, 2005; Slater, 2010). Nutrients from EEFs are released over a fertilizer-specific duration, which is dependent on specific factors intrinsic to each EEF. There are three subgroups of EEFs including slow-release fertilizers (SRFs), stabilized fertilizers (urease and nitrification inhibitors), and CRFs (Carson and Ozores-Hampton, 2012; Sartain et al., 2004).

The terms SRF and CRF are often used interchangeably, but there are important differences. SRFs are longchain molecules with reduced solubility, which release nutrients slower than soluble fertilizers (SFs), but the release duration and pattern are often dependent on the soil microbiology, and thus are not as easily controlled as compared with CRF (Trenkel, 2010). Examples of SRF include urea formaldehyde, isobutydine diurea (IBDU), and sulfur-coated urea (SCU). Nutrient release of SCU is not easily controlled compared with polymer- and resin-coated fertilizers and is subject to locking off (nonrelease) or "burst" release because of cracks in the coating; therefore, it may be considered an SRF (Trenkel, 2010). Stabilized fertilizers are SFs that have either a nitrification inhibitor or a urease inhibitor included (Slater, 2010). Nitrification inhibitors are used to maintain $\mathrm{N}$ in the ammonium $\left(\mathrm{NH}_{4}\right)$ form by depressing or inhibiting activity of bacteria, such as Nitrosomonas sp. and Nitrobacter sp., that transform $\mathrm{NH}_{4}$ into nitrate $\left(\mathrm{NO}_{3}\right)$, which may be leached or further reduced to gaseous nitrous oxide (Trenkel, 1997). The nitrification inhibitors dicyandiamide and 3-amino-1,2,4-triazole reduced nitrification by $28 \%$ and $52 \%$ in subtropical and upland soil conditions (Singh and Verma, 2007). Urease inhibitors slow the urease enzyme that changes urea into ammonia, which is subject to volatilization. $\mathrm{N}$-( $n$-butyl) thiophosphoric triamide, a urease inhibitor, reduced $\mathrm{NH}_{4}$ volatilization by $30 \%$ to $75 \%$ in fine sandy loam soil compared with an untreated control during a 21-d trial (Rawluk et al., 2001). Finally, CRFs are SFs with a coating that consists of polymer or resin, or a hybrid of an outer polymer coating over an SCU (PSCU). Ideally, coatings are formulated to control the release of nutrients to match different crop nutrient requirements (Lammel, 2005). Single SFs or homogenized N-P-K fertilizers may be coated; however, fertilizers with rounded granules coat more uniformly and release more predictably compared to angular fertilizer granules (Tzika et al., 2003).

\section{Vegetable fertility programs in Florida with soluble fertilizers}

When using SFs and seepage irrigation in plasticulture vegetable production, the University of Florida/ Institute of Food and Agricultural Sciences (UF/IFAS) recommends placement of all fertilizer, including $\mathrm{N}$ and $\mathrm{K}$, at bed formation. Traditionally, $10 \%$ to $20 \%$ of the SF-N and SF-K and $100 \%$ of the P and micronutrients are applied in row before bed formation as a "bottom mix." The remaining $\mathrm{N}$ and $\mathrm{K}$ fertilizers are placed in bands on top of the bed, which is referred to as the "top mix." The top mix is placed in one band in the bed center for double row crops such as pepper (Capsicum annumm) or in two bands on the shoulders of the bed in single row crops such as tomato (Solanum lycopersicum) and eggplant (Solanum melongena) (Liu et al., 2012). However, in specific situations, extra dry or liquid SF may be applied to the crop after crop establishment by hand punching holes in the polyethylene mulch or by liquid fertilizer injection wheel. For example, supplemental fertilizer may be added following a leaching rain event (3 inches of rainfall in $3 \mathrm{~d}$ or 4 inches in $7 \mathrm{~d}$ ), an extended harvest season, or a low petiole sap $\mathrm{NO}_{3}$ test result (Cantliffe et al., 2006; OzoresHampton et al., 2012). However, applications of an additional fertilizer are labor intensive and increase production cost. In open-bed vegetable production with seepage irrigation [e.g., potato (Solanum tuberosum)], all $\mathrm{P}$ and micronutrients are applied at planting. A portion (e.g., 60\%) of both $\mathrm{N}$ and $\mathrm{K}$ are banded in the bed at planting or hypocotyl emergence (Hochmuth and Hanlon, 2011). Any remaining soluble $\mathrm{N}$ and $\mathrm{K}$ fertilizer are banded or injected at a later stage of growth [e.g., 6- to 8-inch growth stage (Zotarelli et al., 2012)].

\section{Factors affecting nutrient release from CRF}

Nutrient releases from CRF may be affected by soil factors including temperature, moisture, concentration gradient $\left(\psi_{\mathrm{s}}\right), \mathrm{pH}$, microbial populations, and texture. Factors intrinsic to CRF that may affect nutrient release include nutrient composition, coating thickness, and CRF prill shape and diameter.

Temperature. The rate of nutrient release from CRF increases with increasing soil temperature, which shortens the release duration (Ahmed et al., 1963; Basu et al., 2010; Brown et al., 1966; Carson and OzoresHampton, 2012; Dai et al., 2008; Kochba et al., 1990). Gandeza et al. (1991) showed that after $60 \mathrm{~d}$ of incubation in water, a polymer-coated fertilizer (PCF) released $\approx 20 \%, 48 \%$, and $80 \%$ of the $\mathrm{N}$ at 10,20 , and $30{ }^{\circ} \mathrm{C}$, respectively. On the other hand, Oertli and Lunt (1962) showed that after $60 \mathrm{~d}$, a different PCF released $\approx 50 \% \mathrm{NO}_{3}, 45 \% \mathrm{NH}_{4}, 25 \% \mathrm{~K}$, and $27 \% \mathrm{P}$ at $10{ }^{\circ} \mathrm{C}$, but at $21{ }^{\circ} \mathrm{C}$ the PCF released $\approx 60 \% \mathrm{NO}_{3}, 50 \% \mathrm{NH}_{4}$, $48 \% \mathrm{~K}$, and $48 \% \mathrm{P}$. Similarly, Engelsjord et al. $(1996)$ found $N$ release of $3 \%$ and $12 \%$, and $7 \%$ and $15 \%$ in two different SCU fertilizers during a 6-week laboratory incubation at 4 and $21^{\circ} \mathrm{C}$, respectively. A longer incubation period performed by Lamont et al. (1987) measured nutrient release from resin-coated fertilizer (RCF) at nine temperatures $\left(5\right.$ to $45^{\circ} \mathrm{C}$ ) for 19 weeks and found that nutrient release was quadratic in both time and temperature.

Nutrient release from CRF may be sigmoidal or linear (Trenkel, 2010). The sigmoidal nutrient release pattern of CRF begins with a lag period while water is imbibed into the CRF, then shows a constant rate of release at a given temperature that slows after a given amount of time. The slow phase after the constant nutrient 
release period is known as the decay phase. However, the linear release type CRF lacks a lag phase and begins with a constant release rate that decays as nutrient release slows. It is during the decay phase where the effects of $\psi_{\mathrm{s}}$ are greatest. Du et al. (2006) tested PCF in free water and saturated sand at 20 and $40{ }^{\circ} \mathrm{C}$ and found a decreased CRF lag period and an increased nutrient release rate during the linear release phase at the higher temperature. Diurnal temperature fluctuations cause concomitant increases and decreases in PCF nutrient release (Husby et al., 2003). These diurnal fluctuations may be stabilized to some degree by the use of colored polyethylene mulch. Decoteau et al. (1990) found that planting beds mulched with white polyethylene were $5{ }^{\circ} \mathrm{C}$ lower at $1800 \mathrm{HR}$ than black polyethylene mulched beds. In two other studies, soils with black colored mulch were 1.3 to $1.8{ }^{\circ} \mathrm{C}, 0.8$ to $1.2^{\circ} \mathrm{C}$, and 2.2 to $2.4^{\circ} \mathrm{C}$ higher than bare soil, silver mulched, and white mulched soils, respectively (Diaz-Perez and Batal, 2002; Diaz-Perez et al., 2005). Silver-colored mulch had lower temperature fluctuation throughout the day compared with bare soils. Thus, the effect of mulch color is important for understanding the CRF nutrient release, but mulch color is ultimately dependent on the crop grown.

Florida's vegetable production is seasonal with tomato and pepper being produced during the fall (planting July to 15 Oct.), winter (16 Oct. to 15 Dec.), and spring (16 Dec. to Mar.), while potato is planted from October to January in southwestern Florida (Olson et al., 2012; OzoresHampton et al., 2006). Thus, the fall growing season begins with high and ends with lower air temperatures or the spring season begins with low and ends with higher air temperatures (Ozores-Hampton et al., 2006). According to Zheng et al. (1993), soil temperature and air temperature are highly correlated $\left(R^{2}=0.85\right.$ to 0.96 ) and soil temperature may be predicted using air temperature. Using the above planting dates, a season length of 18 and 16 weeks for fall and spring, and a 6-week harvest, the average air temperatures during planting and harvest for the Fall 2011 and Spring 2012 seasons were 26.7 and $20.6^{\circ} \mathrm{C}$, and 18.2 and $21.9^{\circ} \mathrm{C}$, respectively (Florida Automated Weather Network, 2012; OzoresHampton et al., 2006). The average soil temperatures during the same time periods were 28.0 and $22.5^{\circ} \mathrm{C}$, and 19.9 and $23.7^{\circ} \mathrm{C}$, respectively (Florida Automated Weather Network, 2012). Thus, average soil temperatures were between 1.3 and $1.9^{\circ} \mathrm{C}$ higher compared with the average air temperature. The high air and soil temperatures, relative to the temperature at which manufactures determine nutrient release duration (e.g., $75^{\circ} \mathrm{F}$ ), during the beginning and throughout the fall season will shorten the CRF release duration by decreasing the lag period and increasing the rate during the linear release phase; thus, a release duration longer than the season may be necessary (Carson et al., 2013; Du et al., 2006). However, the lower average air temperatures during the spring, relative to the release duration determination temperature, will extend the CRF-release duration, and a CRF with a release duration of the season length may be more appropriate.

SoIL MOISTURE. Water vapor infiltration into CRF prills is a limiting factor for nutrient release from CRF [potassium nitrate $\left(\mathrm{KNO}_{3}\right)$ ] at soil moisture of less than $50 \%$ field capacity (Kochba et al., 1990). Nutrient release from a different CRF [ammonium nitrate $\left.\left(\mathrm{NH}_{4} \mathrm{NO}_{3}\right)\right]$ was unaffected by soil moisture levels between field capacity and permanent wilting point (Lunt and Oertli, 1962). Ahmed et al. (1963) indicated that release varies because of soil moisture content and the SF type occluded within the PCF. Nutrient release from PCF (ammonium phosphate) was independent of the soil moisture content between field capacity and 25\% field capacity. However, PCF $\left(\mathrm{KNO}_{3}\right)$ released faster at $100 \%$ and $75 \%$ than $50 \%$ and $25 \%$ field capacity. At soil water potentials below the permanent wilting point, water vapor movement into CRF prills limits nutrient release. However, under well-managed production systems, soil moisture should be managed for optimal crop production, which keeps soil moisture at ideal levels for nutrient release from a CRF.

Osmotic potential. Several CRF mechanistic nutrient release models incorporate nutrient diffusion from CRFs prills (Basu et al., 2010;
Holcomb, 1981; Shaviv et al., 2003a, $2003 \mathrm{~b})$. A large nutrient-specific $\psi_{\mathrm{S}}$ is present inside the CRF prill as compared with the soil solution (Shaviv et al., 2003a). Therefore, the rate of nutrient release from CRF is dependent on the $\psi_{\mathrm{S}}$ difference between the soil solution and the CRF. Shaviv et al. (2003a) explain that during the lag phase of nutrient release, water enters the fertilizer prill and is followed by a linear phase with constant release where the $\psi_{\mathrm{S}}$ are equilibrating and eventually enters a decay phase where the $\psi_{\mathrm{S}}$ become equilibrated. However, Oertli and Lunt (1962) found no effect of salt concentration on nutrient release, but postulated that different conditions such as low soil moisture concentration would cause solute accumulation around the CRF prill, which may elevate salt concentrations around the CRF prill to the levels that may slow nutrient release.

SoIL $\mathrm{pH}$. Soil $\mathrm{pH}$ has not been shown to have a direct effect on the CRF (PCF and RCF) (Basu et al., 2010; Christianson, 1988; Oertli and Lunt, 1962). However, low soil $\mathrm{pH}$ may slow the release of SCU because of the $\mathrm{pH}$ effect on soil microbes (Jarrell and Boersma, 1979).

SoIl Microbial populations. When exposed to sterilized soil and nonsterilized soils, nutrient release from RCF was similar (Oertli and Lunt, 1962). Salman et al. (1989) found that microorganisms had no effect on nutrient release from PCF but did affect urea release from SCU. Similarly, soil microbes did not affect $\mathrm{N}$ release from reactive layer-coated fertilizers, a type of PCF (Christianson, 1988). However, speciation of soil $\mathrm{N}$ $\left(\mathrm{NH}_{4}\right.$ or $\left.\mathrm{NO}_{3}\right)$ and plant growth will be affected by soil microbes after release. In a Florida winter tomato growing season, $29 \%$ and $54 \%$ plant mortality occurred with two different polymer-coated urea (PCU) fertilizers applied in fumigated soil under virtually impermeable polyethylene mulch because of accumulation of $\mathrm{NH}_{4}$ (Ozores-Hampton et al., 2009).

SoIL TeXture. Soil texture alone does not influence nutrient release from CRF. However, soil texture does influence soil moisture holding capacity and to some extent temperature, which do affect CRF nutrient release (Ahmed et al., 1963; Salman et al., 1989). Nutrient release from PCF 
(urea, $\mathrm{KNO}_{3}$, and ammonium phosphate) was similar in sandy loam and silt loam soils (Ahmed et al., 1963). Urea release from PCU was similar when incubated in water, sandy soil, or soil from a paddy rice field (Salman et al., 1989).

CONTROLLED-RELEASE FERTILIZER COMPosition. Although the nutrient core of some CRF contains a single fertilizer such as urea, many contain multiple nutrients within the prill, which have been shown to release differently. Du et al. (2006) measured nutrient release from a PCF $(\mathrm{N}-\mathrm{P}-\mathrm{K})$ at three moisture levels and found that at each moisture level release of $\mathrm{NO}_{3}>\mathrm{K}>\mathrm{P}$ as a fractional percentage of total nutrients. For instance, a PCF $(\mathrm{N}-\mathrm{P}-\mathrm{K})$ incubated in free water for $60 \mathrm{~d}$ at $30{ }^{\circ} \mathrm{C}$ released $82 \% \mathrm{NO}_{3}, 79 \%$ $\mathrm{K}$, and $42 \% \mathrm{P}$. This relative order remained for all the three water levels. Similarly, Huett and Gogel (2000) measured nutrient release from PCF in a column study and found release rates were $\mathrm{N}>\mathrm{K}>\mathrm{P}$ at both 30 and $40{ }^{\circ} \mathrm{C}$. In two studies, $\mathrm{N}$ release from several CRFs was speciated and found that release of $\mathrm{NO}_{3} \geq \mathrm{NH}_{4}>\mathrm{K}>\mathrm{P}$ (Broschat, 2005; Broschat and Moore, 2007).

The specific SF (i.e., urea or $\mathrm{KNO}_{3}$ ) that is coated may influence the water vapor infiltration rate because of variations in salt index among the fertilizers. Fertilizers with a higher salt index have a higher water-vaporpressure-lowering capacity compared with fertilizers with a lower salt index; thus, a CRF with a higher salt index will have a higher water absorption rate and faster solubilization of the solid fertilizer core (Attoe et al., 1970). Water-vapor-lowering capacity and solubility increase with increasing temperature; thus, the CRF prill solution may become saturated at a higher concentration compared with lower temperatures, which will increase the $\psi_{S}$ further between the prill and the soil solution. Ahmed et al. (1963) reported that CRFs incubated in soil at room temperature and field capacity had different release rates because of the fertilizer core, such that urea was released from the prill faster than ammonium phosphate, which released faster than $\mathrm{KNO}_{3}$; these release rates relate to the order of solubility and vapor pressure lowering capacity. Broschat and Moore (2007) found that PCF micronutrients were released slower than PCF macronutrients, which purportedly was not due to precipitation with P. However, sulfates of magnesium and iron have lower solubility compared with many macronutrient fertilizers such as $\mathrm{NH}_{4} \mathrm{NO}_{3}$, diammonium phosphate, and $\mathrm{KNO}_{3}$, while manganese sulfate has a lower solubility compared with $\mathrm{NH}_{4} \mathrm{NO}_{3}$ and $\mathrm{KNO}_{3}$. The differences in solubility may help explain the slower release rates of micronutrients. The relationship of fertilizer solubility and vapor pressure reduction with temperature partially explains the nutrient release rate change with temperature (Attoe et al., 1970).

COATING THICKNESS, TYPE, AND PRILL DIAMETER. The duration of the nutrient release period of SCU, RCF, PCF, and PSCU is adjusted by coating thickness; thus, thicker coatings have longer release durations (Brown et al., 1966; Du et al., 2006; Fan, 2009; Ko et al., 1996; Shaviv et al., 2003b; Trenkel, 2010). In addition, nutrient release rates of PCF, RCF, and hybrid-coated fertilizer may be adjusted by modifying the ratios of coatings. For instance, increasing the percentage of polymer in the polymerto-solvent ratio of a polysulfone coating increases the release period (Tomaszewska and Jarosiewicz, 2002). Similarly, increasing the amount of plasticizer in the plasticizer-to-ethylcellulose ratio increases the release period (PerezGarcia et al., 2007). Larger diameter CRF prills have a longer nutrient release period (e.g., a 2-mm-diameter CRF prill released $\mathrm{N}$ more slowly compared with a l-mm-diameter CRF prill) (Perez-Garcia et al., 2007; Shaviv, 2001).

\section{Cultural practices affecting CRF release duration}

CRF FIELD PLACEMENT. In plasticulture vegetable production, when SRFs [methylene urea (MU)] and CRFs [RCF (urea and $\mathrm{KNO}_{3}$ ) and PSCU] were used as a singular $\mathrm{N}$ source in the bottom mix during a spring season, lower or similar extralarge and total marketable tomato yields were found as compared with SFs (Csizinszky, 1994). In contrast, when PCU was used with soluble N in the bottom mix during the fall season, marketable tomato yield was similar or greater than yields using an SF (Ozores-Hampton et al., 2009).
However, detrimental effects were found when placing PCU as a bottom mix during the winter production season because of low soil $\mathrm{NO}_{3}$ concentrations or plant mortality associated with $\mathrm{NH}_{4}$ toxicity [Table 1 (Csizinszky et al., 1993; OzoresHampton et al., 2009)]. Csizinszky (1989), Csizinszky et al. (1992) and Ozores-Hampton et al. (2009) applied EEFs (oxamide, MU, PCU, IBDU, and SCU) in plasticulture production during the spring, fall, and spring, respectively, as a top mix, and found similar or lower total marketable tomato yields compared with an $\mathrm{SF}$ at similar $\mathrm{N}$ rates. These results were due to slow $\mathrm{N}$ release from the SRF or CRF, which caused low $\mathrm{NH}_{4}$ and $\mathrm{NO}_{3}$ soil concentration during the season (Csizinszky, 1994; OzoresHampton et al., 2009). Thus, do not place CRF as a part of the top mix in seepage-irrigated plasticulture production. To increase $\mathrm{NH}_{4}$ and $\mathrm{NO}_{3}$ soil solution concentration during the tomato growing season, a "hybrid fertilizer system" was created containing $60 \%$ to $80 \%$ of the $\mathrm{N}$ as CRFs applied as a bottom mix with the remainder of the $\mathrm{N}$ as $\mathrm{SF}$ in the top mix (Ozores-Hampton et al., 2009). In a winter season, similar marketable tomato yields were found when comparing SF and the hybrid fertilizer system using $\mathrm{CRF}\left(\mathrm{KNO}_{3}\right)$ at equal and $25 \%$ reduced total $\mathrm{N}$ rates (OzoresHampton et al., 2009). Hochmuth et al. (1994) applied CRF-K in the bottom mix to bell peppers and found no increase in earliness or total-season yields (Table 2). However, Csizinszky (1994) found increased early, fancy bell pepper yields using RCF (urea and $\mathrm{KNO}_{3}$ ) in a hybrid fertilizer system, but treatments had similar total marketable yield. Thus, CRFs placed in a hybrid fertilizer system have shown improved performance compared with CRFs placed as a single $\mathrm{N}$ source in the bottom mix or top mix. Furthermore, placement of a CRF in a hybrid fertilizer system has the potential to produce equal marketable tomato yield at equal or lower $\mathrm{N}$ rates compared with SFs (Carson et al., 2012; OzoresHampton et al., 2009).

In open-bed (no polyethylene mulch) production, Hutchinson (2005) and Pack et al. (2006) incorporated PCU into potato hills and found positive results compared to an SF (Table 3). However, Hutchinson 


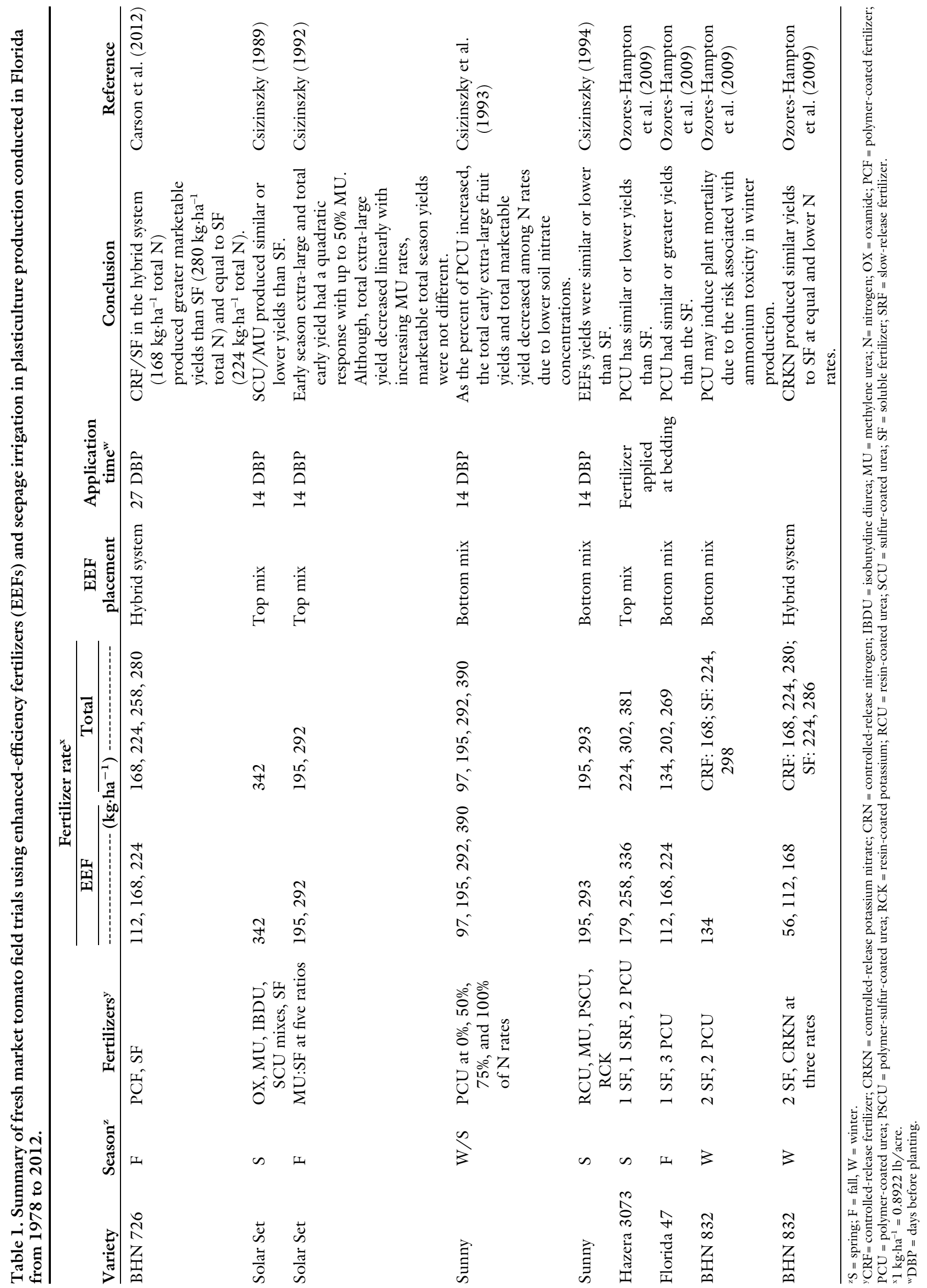

Hortlechnology • October $201323(5)$ 


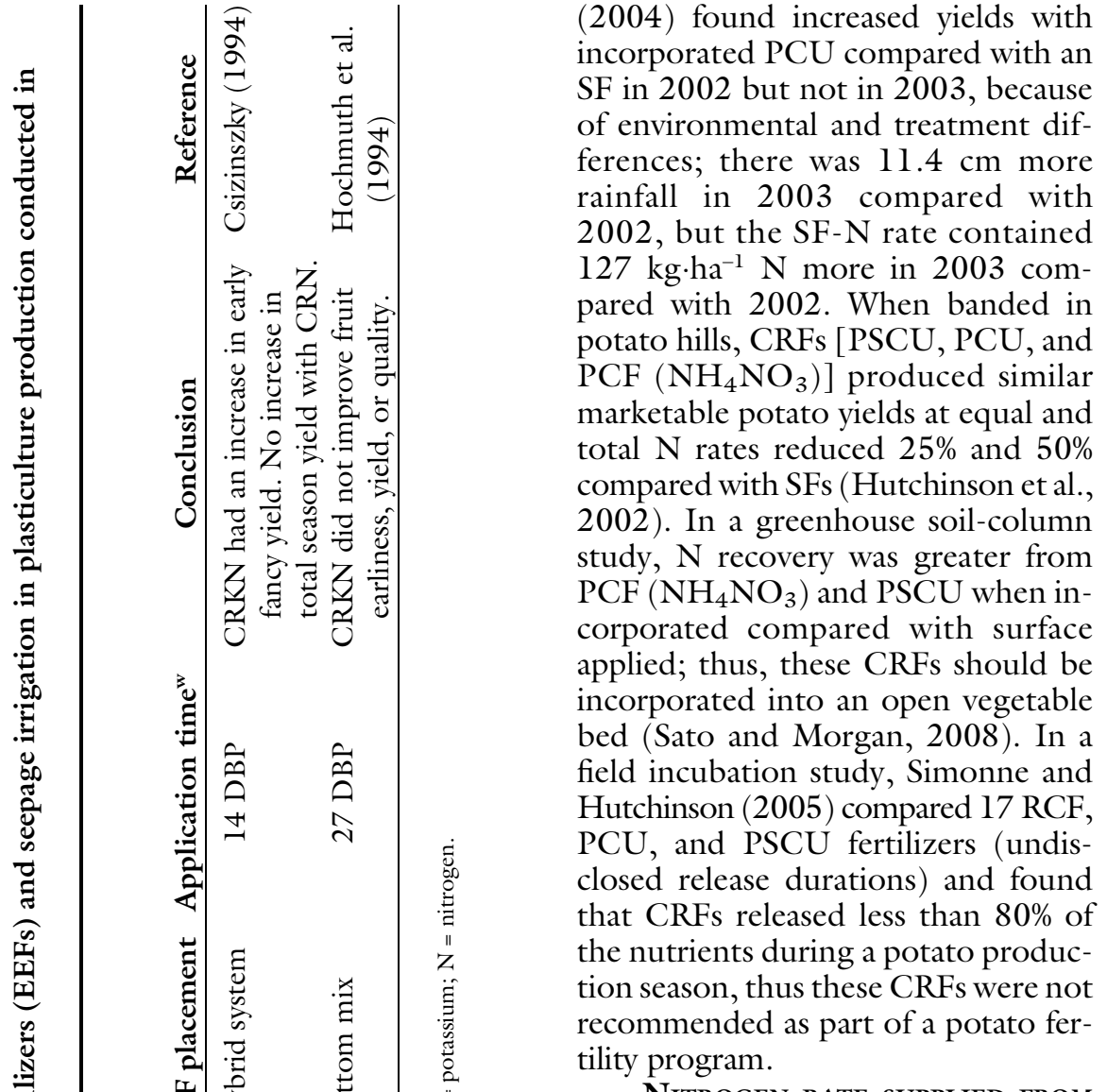

Nitrogen RATE SUPPLIED FROM CRFs. In Florida, for tomato planted on $6-\mathrm{ft}$ centers, the UF/IFAS N recommendation is $224 \mathrm{~kg} \cdot \mathrm{ha}^{-1}$ for all planting seasons, tomato varieties, soil and irrigation types, with allowances for supplemental $\mathrm{N}$ applications (Olson et al., 2011). Growers typically follow UF/IFAS irrigation recommendations, but use $\mathrm{N}$ fertilizer rates greater than the UF/IFAS recommendation (Cantliffe et al., 2006). Since EEFs increase nutrient use efficiency by maintaining nutrients in the root zone, growers may potentially reduce $\mathrm{N}$ and $\mathrm{K}$ fertilizer rates to those recommended by UF/IFAS or below. In plasticulture production, Csizinszky et al. (1993) conducted an $\mathrm{N}$-rate study replacing a portion of the total $\mathrm{N}(0 \%, 50 \%, 75 \%$, or $100 \%$ ) with controlled-release urea (CRU) in the bottom mix (Table 1 ). No differences in early extra-large or season total marketable tomato yield because of $\mathrm{N}$ rate were found; however, season total marketable yield decreased linearly as CRU percent increased. Ozores-Hampton et al. (2009) found reduced early extralarge tomato yield using PCU at reduced total $\mathrm{N}$ rates compared with an $\mathrm{SF}$ in a winter season, which was due to lower plant biomass and plant mortality with the CRFs. Reduced tomato yields with CRU were probably related to $\mathrm{N}$ source rather than $\mathrm{N}$ rate. Thus, research is being conducted using "tomato friendly" coated nutrients such as a coated $\mathrm{KNO}_{3}$ fertilizer with different coating technologies compared with previous studies. Further research using PCU and a soluble $\mathrm{NO}_{3}$ source in a hybrid system is being conducted to ameliorate the source effects and to determine if reduced $\mathrm{N}$ rates will produce equal or greater tomato yields and quality when compared with growers' practices.

In an open-bed production system using CRF treatments of PCF, PSCU, and PCU at $168 \mathrm{~kg} \cdot \mathrm{ha}^{-1} \mathrm{~N}$, equal or greater marketable potato yields resulted with the CRFs compared with SF treatments at $224 \mathrm{~kg} \cdot \mathrm{ha}^{-1}$ $\mathrm{N}$ [Hutchinson, 2004; Hutchinson et al., 2002 (Table 3)]. Hutchinson (2005) reported that of nine CRF treatments at $168 \mathrm{~kg} \cdot \mathrm{ha}^{-1} \mathrm{~N}$, seven treatments produced greater marketable potato yields compared with SF-N treatments at $168 \mathrm{~kg} \cdot \mathrm{ha}^{-1} \mathrm{~N}$ and eight of treatments produced yields equal to SF-N at $224 \mathrm{~kg} \cdot \mathrm{ha}^{-1} \mathrm{~N}$. Chen and Hutchinson (2008) found similar marketable potato yields with PSCU $\left(196 \mathrm{~kg} \cdot \mathrm{ha}^{-1}\right.$ ) applied at planting compared with split-applied SF (224 and $\left.280 \mathrm{~kg} \cdot \mathrm{ha}^{-1}\right)$. Pack et al. (2006) reported no marketable potato yield difference between two CRF-N rates, 146 and $225 \mathrm{~kg} \cdot \mathrm{ha}^{-1} \mathrm{~N}$. Therefore, it may be concluded that CRFs have the potential to reduce $\mathrm{N}$ rates by up to $25 \%$ or more and maintain potato yield and quality.

CRF APPLICATION TIMING. Plasticulture vegetable production practices with seepage irrigation include application of all fertilizers (CRF and $\mathrm{SF}$ ) at bed formation (Table 1 ). The exception (discussed above) would be side-dress applications to crops grown with an SF. Side-dressed applications are, ideally, eliminated with the use of a CRF (Cantliffe et al., 2006). However, in vegetable production using open-beds, SFs typically are split applied (Zotarelli et al., 2012). Chen and Hutchinson (2008) applied PSCU and PCU with and without an SF-N to potato as a split application and found that higher yields were obtained when CRFs were applied at or before planting (Table 3 ). Elkashif et al. (1983) found a significant 


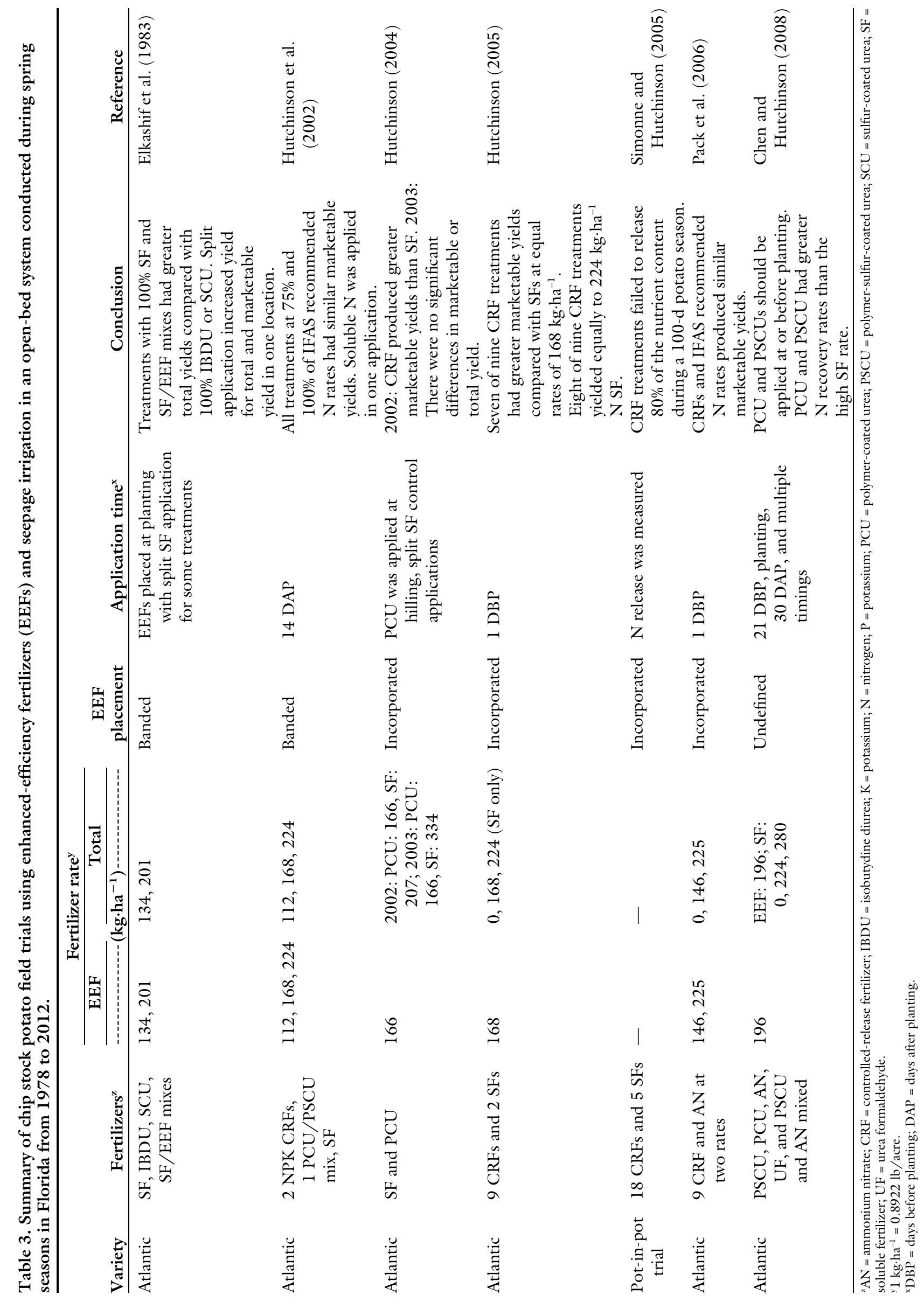

Hortlechnology • October 2013 23(5) 
increase in total and marketable potato yield in one of the two locations for two IBDU treatments and an SCU treatment that were banded at planting and side-dressed with an SF$\mathrm{N}\left(\mathrm{NH}_{4} \mathrm{NO}_{3}\right)$ compared with treatments where all fertilizers $\left(\mathrm{NH}_{4} \mathrm{NO}_{3}\right.$, SCU, or IBDU) was placed at planting. In the second location, application timing was not significant, but the three split-applied treatments had greater yield than the IBDU and SCU treatments where $100 \%$ of the fertilizer was applied at planting. In an open-bed production, CRF should be applied at planting, which may eliminate the need to side-dress (depending on environment and $\mathrm{N}$ source) and reduce the number of equipment passes across the field, thereby reducing production cost (Hutchinson and Simonne, 2003; Shoji et al., 2001).

Fumigation AND STAGED PLANTING. Plasticulture vegetable production uses soil fumigation and staged planting or several planting dates in beds fumigated on the same day. Soil fumigants such as metam sodium/ potassium, chloropicirin, dimethyl disulfide, and 1,3-dichloropropene have a 2 - to 3 -week lag period between bedding and safe planting. Vegetable beds are formed when soil conditions are appropriate (i.e., moisture content), which may be attained after rainfall or irrigation; however, vegetables are planted in stages to allow for continual harvests. Thus, up to an additional 3 weeks may be added to the fumigation lag period for the projected planting date. Therefore, CRFs may be selected based on a total-season length of 18 to 26 weeks, which includes 2 to 3 weeks for fumigation requirements, 0 to 3 weeks for projected planting date, and 16 to 20 weeks for regular cropping season length.

Incorporation of CRF into a vegetable fertility program for plasticulture and open-beds in Florida requires awareness of the expected soil temperature during the growing season, which will help determine the appropriate CRF release period together with optimal crop soil moisture. For plasticulture vegetable production using seepage irrigation, best results with CRF have been obtained with $60 \%$ to $80 \%$ of the $\mathrm{N}$ as CRF and the remainder as SF. In an open-bed production system, optimal results will be obtained by incorporating CRF into the bed at or before planting. Use of a CRF in these methods may eliminate the need for side-dressed fertilizer applications. In addition, the use of a CRF with recommended production practices will allow for up to a $25 \%$ reduction in $\mathrm{N}$ application rates.

\section{Literature cited}

Ahmed, I.U., O.J. Attoe, L.E. Engelbert, and R.B. Corey. 1963. Factors affecting the rate of release of fertilizer from capsules. Agron. J. 55:495-499.

Attoe, O.J., F.L. Rasson, W.C. Dahnke, and J.R. Boyle. 1970. Fertilizer release from packets and its effect on tree growth. Soil Sci. Soc. Amer. J. 34:137-142.

Bartnick, B., G. Hochmuth, J. Hornsby, and E. Simonne. 2005. Water quality/quantity best management practices for Florida vegetable and agronomic crops. 7 Aug. 2013. <http://www.floridaagwaterpolicy. com/PDF/Bmps/Bmp_VeggieAgroCrops 2005.pdfs.

Basu, S.K., N. Kumar, and J.P. Srivastava. 2010. Modeling NPK release from spherically coated fertilizer granules. Simul. Model. Pract. Theory 18:820-835.

Bonczek, J.L. and B.L. McNeal. 1996. Specific-gravity effects on fertilizer leaching from surface sources to shallow water tables. Soil Sci. Soc. Amer. J. 60:978985.

Broschat, T.K. 2005. Rates of ammoniumnitrogen, nitrate-nitrogen, phosphorus, and potassium from two controlled-release fertilizers under different substrate environments. HortTechnology 15:332-335.

Broschat, T.K. and K.K. Moore. 2007. Release rates of ammonium-nitrogen, nitrate-nitrogen, phosphorus, potassium, magnesium, iron, and manganese from seven controlled-release fertilizers. Commun. Soil Sci. Plant Anal. 38:843-850.

Brown, M.J., R.E. Luebs, and P.F. Pratt. 1966. Effect of temperature and coating thickness on the release of urea from resin-coated granules. Agron. J. 58:175178.

Cantliffe, D., P. Gilreath, D. Haman, C. Hutchinson, Y. Li, G. McAvoy, K. Migliaccio, T. Olczyk, S. Olson, D. Parmenter, B. Santos, S. Shukla, E. Simonne, C. Stanley, and A. Whidden. 2006. Review of nutrient management systems for Florida vegetable producers: A white paper from the UF/ IFAS vegetable fertilizer task force. Proc. Florida. State Hort. Soc. 119:240-248.

Carson, L.C. and M. Ozores-Hampton. 2012. Methods for determining nitrogen release from controlled-release fertilizers used for vegetable production. HortTechnology 22:20-24.

Carson, L.C., M. Ozores-Hampton, and K.T. Morgan. 2012. Effect of controlledrelease and soluble fertilizer on tomato grown with seepage irrigation in Florida sandy soils. Proc. Florida State Hort. Soc. 125:164-168.

Carson, L.C., M. Ozores-Hampton, and K.T. Morgan. 2013. Nitrogen release from controlled-release fertilizers in seepage-irrigated tomato production in south Florida. Proc. Florida State Hort. Soc. 126: (In Press).

Chen, Z. and C.M. Hutchinson. 2008. Evaluation of alternative fertilizer programs in seepage irrigated potato production. Proc. Florida State Hort. Soc. 121:187-190.

Christianson, C.B. 1988. Factors affecting $\mathrm{N}$ release of urea from reactive layer coated urea. Fert. Res. 16:273-284.

Csizinszky, A.A. 1989. Effect of controlled (slow) release nitrogen sources on tomato, Lycopersicon esculentum Mill. cv. Solar Set. Proc. Florida State Hort. Soc. 102:348-351.

Csizinszky, A.A., G.A. Clark, and C.D. Stanley. 1992. Evaluation of methylene urea for fresh-market tomato with seepage irrigation. Proc. Florida State Hort. Soc. 105:370-372.

Csizinszky, A.A. 1994. Yield response of bell pepper and tomato to controlledrelease fertilizers on sand. J. Plant Nutr. 17:1535-1549.

Csizinszky, A.A., C.D. Stanley, and G.A. Clark. 1993. Evaluation of controlledrelease urea for fresh market tomato. Proc. Florida State Hort. Soc. 106:183-187.

Dai, J., X. Fan, J. Yu, F. Liu, and Q. Zhang. 2008. Study on the rapid method to predict longevity of controlled release fertilizer coated by water soluble resin. Agr. Sci. China 7:1127-1132.

Decoteau, D.R., M.J. Kasperbauer, and P.G. Hunt. 1990. Bell pepper plant development over mulches of diverse colors. HortScience 25:460-462.

Diaz-Perez, J.C. and K.D. Batal. 2002. Colored plastic film mulches affect tomato growth and yield via changes in root-zone temperature. J. Amer. Soc. Hort. Sci. 127:127-135.

Diaz-Perez, J.C., S.C. Phatak, D. Giddings, and D. Bertrand. 2005. Root zone temperature, plant growth, and fruit yield of tomatillo as affected by plastic film mulch. HortScience 40:1312-1319.

Du, C., J. Zhou, and A. Shaviv. 2006. Release characteristics of nutrients from 
polymer-coated compound controlled release fertilizers. J. Polym. Environ. $14: 223-230$

Elkashif, M.E., S.J. Locascio, and D.R. Hensel. 1983. Isobutylidene diurea and sulfur-coated urea as $\mathrm{N}$ source for potatoes. J. Amer. Soc. Hort. Sci. 108:523526.

Engelsjord, M., O. Fostad, and B. Singh. 1996. Effects of temperature on nutrient release from slow-release fertilizers. Nutr. Cycl. Agroecosyst. 46:179-187.

Fan, X. 2009. Research and development of controlled-release fertilizers as high efficient nutrient management materials in China. Proc. Intl. Plant Nutr. Colloq. $16: 1-6$

Florida Automated Weather Network. 2012. Archived weather data. 14 Nov. 2012. <http://fawn.ifas.ufl.edu/data/>

Gandeza, A.T., S. Shoji, and I. Yamada. 1991. Simulation of crop response to polyolefin-coated urea: I. Field dissolution. Soil Sci. Soc. Amer. J. 55:1462-1467.

Hochmuth, G. and E. Hanlon. 2011. A summary of $\mathrm{N}, \mathrm{P}$, and $\mathrm{K}$ research with potato in Florida. Univ. Florida, Inst. Food Agr. Sci., Electronic Data Info. Source SL346.

Hochmuth, G., K. Shuler, E. Hanlon, and N. Roe. 1994. Pepper response to fertilization with soluble and controlledrelease potassium fertilizers. Proc. Florida State Hort. Soc. 107:132-139.

Holcomb, E.J. 1981. A technique for determining potassium release from a slow-release fertilizer. Commun. Soil Sci. Plant Anal. 12:271-277.

Huett, D.O. and B.J. Gogel. 2000. Longevities and nitrogen, phosphorus, and potassium release patterns of polymercoated controlled-release fertilizers at $30^{\circ} \mathrm{C}$ and $40^{\circ} \mathrm{C}$. Commun. Soil Sci. Plant Anal. 31:959-973.

Husby, C.E., A.X. Niemiera, J.R. Harris, and R.D. Wright. 2003. Influence of diurnal temperature on nutrient release patterns of three polymer-coated fertilizers. HortScience 38:387-389.

Hutchinson, C.M. 2004. Controlled release fertilizer potato production system for Florida. Proc. Florida State Hort. Soc. 117:76-78.

Hutchinson, C.M. 2005. Influence of a controlled release nitrogen fertilizer program on potato (Solanum tuberosum L.) tuber yield and quality. Acta Hort. 684:99-102.

Hutchinson, C.M. and E.H. Simonne. 2003. Controlled-release fertilizer opportunities and costs for potato production in Florida.
Univ. Florida, Inst. Food Agr. Sci., Electronic Data Info. Source HS941.

Hutchinson, C., E. Simonne, P. Solano, J. Meldrum, and P. Livingston-Way. 2002. Testing of controlled release fertilizer programs for seep irrigated Irish potato production. J. Plant Nutr. 26:17091723.

Jarrell, W.M. and L. Boersma. 1979. Model for the release of urea by granules of sulfur-coated urea applied to soil. Soil Sci. Soc. Amer. J. 43:1044-1050.

Ko, B.S., Y.S. Cho, and H.K. Rhee. 1996. Controlled release of urea from rosincoated fertilizer particles. Ind. Eng. Chem. Res. 35:250-257.

Kochba, M., S. Gambash, and Y. Avnimelech. 1990. Studies on slow release fertilizers: I. Effects of temperature, soil moisture, and water vapor pressure. Soil Sci. 149:339-343.

Lammel, J. 2005. Cost of the different options available to farmers: Current situation and prospects. Intl. Wkshp Enhanced-Efficiency Fert., Frankfurt, Germany, 28-30 June 2005. Intl. Fert. Assn., Paris, France.

Lamont, G.P., R.J. Worrall, and M.A. O'Connell. 1987. The effects of temperature and time on the solubility of resincoated controlled-release fertilizers under laboratory and field conditions. Sci. Hort. 32:265-273.

Liu, G.D., E.H. Simonne, and G.J. Hochmuth. 2012. Soil and fertilizer management for vegetable production in Florida, p. 3-15. In: S.M. Olson and B.S. Santos (eds.). Vegetable production handbook for Florida. Univ. Florida, Inst. Food Agr. Sci., Gainesville, FL.

Lunt, O.R. and J.J. Oertli. 1962. Controlled release of fertilizer minerals by encapsulating membranes: II. Efficiency of recovery, influence of soil moisture, mode of application, and other considerations related to use. Soil Sci. Soc. Amer. J. 26:584-587.

Oertli, J.J. and O.R. Lunt. 1962. Controlled release of fertilizer minerals by incapsulating membranes: I. Factors influencing the rate of release. Soil Sci. Soc. Amer. J. 26:579-583.

Olson, S.M., P.J. Dittmar, G.E. Vallad, S.E. Webb, E.J. McAvoy, S.A. Smith, M. Ozores-Hampton, and B.M. Santos. 2012. Pepper production in Florida, p. 223-242. In: S.M. Olson and B. Santos (eds.). Vegetable production handbook for Florida. Vance, Lenexa, KS.

Olson, S.M., W.M. Stall, G.E. Vallad, S.E. Webb, S.A. Smith, E.H. Simonne, E.J. McAvoy, and B.M. Santos. 2011. Tomato production in Florida, p. 295-315. In:
S.M. Olson and B. Santos (eds.). Vegetable production handbook for Florida. Vance, Lenexa, KS.

Ozores-Hampton, M.P., E.J. McAvoy, M. Lambert, and D. Sui. 2011. A survey of the effectiveness of current methods used for the freeze protection of vegetables in south Florida. Proc. Florida State Hort. Soc. 123:128-133.

Ozores-Hampton, M.P., E.H. Simonne, K. Morgan, K. Cushman, S. Sato, C. Albright, E. Waldo, and A. Polak. 2009. Can we use controlled release fertilizers $(\mathrm{CRF})$ in tomato production? Florida Tomato Inst. Proc. 525:12-17.

Ozores-Hampton, M.P., E. Simonne, E. McAvoy, P. Stansly, S. Shukla, P. Roberts, F. Roka, T. Obreza, K. Cushman, P. Gilreath, and D. Parmenter. 2006. Nitrogen best management practice with tomato production in Florida in the 2005-2006 season. Proc. Florida State Hort. Soc. 119:284-288.

Ozores-Hampton, M., E. Simonne, F. Roka, K. Morgan, S. Sargent, C. Snodgrass, and E. McAvoy. 2012. Nitrogen rates effects on the yield, nutritional status, fruit quality, and profitability of tomato grown in the spring with subsurface irrigation. HortScience 47:1129-1133.

Pack, J.E., C.M. Hutchinson, and E.H. Simonne. 2006. Evaluation of controlledrelease fertilizers for northeast Florida chip potato production. J. Plant Nutr. 29:1301-1313.

Perez-Garcia, S., M. Fernandez-Perez, M. Villafranca-Sanchez, E. Gonzalez-Pradas, and F. Flores-Cespedes. 2007. Controlled release of ammonium nitrate from ethylcellulose coated formulations. Ind. Eng. Chem. Res. 46:3304-3311.

Rawluk, C.D.L., C.A. Grant, and G.J. Racz. 2001. Ammonia volatilization from soils fertilized with urea and varying rates of urease inhibitor NBPT. Can. J. Soil Sci. 81:239-246.

Salman, O.A., G. Hovakeemian, and N. Khraishi. 1989. Polyethylene-coated urea. 2. Urea release as affected by coating material, soil type and temperature. Ind. Eng. Chem. Res. 28:633-638.

Sartain, J.B., W.L. Hall, R.C. Littell, and E.W. Hopwood. 2004. New tools for the analysis and characterization of slowrelease fertilizers, p. 180-195. In: W.L. Hall and W.P. Robarge (eds.). Environmental impact of fertilizer on soil and water. Amer. Chem. Soc., Washington, DC.

Sato, S. and K.T. Morgan. 2008. Nitrogen recovery and transformation from a surface or sub-surface application of controlled-release fertilizer on a sandy soil. J. Plant Nutr. 31:2214-2231. 


\section{Reviews}

Shaviv, A., S. Raban, and E. Zaidel. 2003a. Modeling controlled nutrient release from polymer coated fertilizers:Diffusion release from single granules. Environ. Sci. Technol. 37:2251-2256.

Shaviv, A., S. Raban, and E. Zaidel. 2003b. Modeling controlled nutrient release from a population of polymer coated fertilizers: Statistically based model for diffusion release. Environ. Sci. Technol. 37:2257-2261.

Shaviv, A. 2001. Advances in controlledrelease fertilizers. Adv. Agron. 71:1-49.

Shoji, S., J. Delgado, A. Mosier, and Y. Miura. 2001. Use of controlled release fertilizers and nitrification inhibitors to increase nitrogen use efficiency and to conserve air and water quality. Commun. Soil Sci. Plant Anal. 32:1051-1070.

Simonne, E.H. and C.M. Hutchinson. 2005. Controlled-release fertilizers for vegetable production in the era of best management practices: Teaching new tricks to an old dog. HortTechnology $15: 36-46$.

Singh, S.N. and A. Verma. 2007. The potential of nitrification inhibitors to manage the pollution effect of nitrogen fertilizers in agricultural and other soils: A review. Environ. Pract. 9:266-279.

Slater, J.V. (ed). 2010. Official Publication AAPFCO. Assn. Amer. Plant Food Control Officials, West Lafayette, IN.

Tomaszewska, M. and A. Jarosiewicz. 2002. Use of polysulfone in controlledrelease NPK fertilizer formulations. J. Agr. Food Chem. 50:4634-4639.

Trenkel, M.E. 1997. Controlled-release and stabilized fertilizers in agriculture. Intl. Fert. Ind. Assn., Paris, France.

Trenkel, M.E. 2010. Slow- and controlled release and stabilized fertilizers: An option for enhancing nutrient use efficiency in agriculture. 2nd ed. Intl. Fert. Ind. Assn., Paris, France.
Tzika, M., S. Alexandridou, and C. Kiparissides. 2003. Evaluation of the morphological and release characteristics of coated fertilizer granules produced in a Wurster fluidized bed. Powder Technol. 132:16-24.

U.S. Environmental Protection Agency. 2009. Clean Water Act Section 303. U.S. Environ. Protection Agency, Washington, DC.

Zheng, D., E.R. Hunt, Jr., and S.W. Running. 1993. A daily soil temperature model based on air temperature and precipitation for continental applications. Clim. Res. 2:183-191.

Zotarelli, L., P.D. Roberts, P.J. Dittmar, S.E. Webb, S.A. Smith, B.M. Santos, and S.M. Olson. 2012. Potato production in Florida, p. 243-259. In: S.M. Olson and B.M. Santos (eds.). Vegetable production handbook for Florida. Vance, Lenexa, KS. 